Article

\title{
Identifying and Assessing Sustainable Value Management Implementation Activities in Developing Countries: The Case of Egypt
}

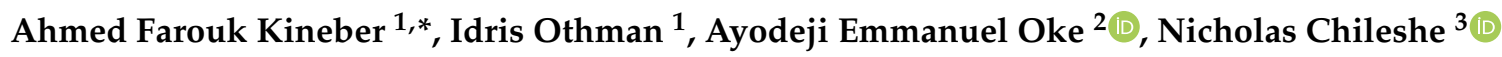 \\ and Mohanad Kamil Buniya ${ }^{1}$ \\ 1 Department of Civil \& Environmental Engineering, Universiti Technologi PETRONAS, \\ Seri Iskandar 32610, Malaysia; idris_othman@utp.edu.my (I.O.); mohanad_18000491@utp.edu.my (M.K.B.) \\ 2 Department of Quantity Surveying, Federal University of Technology Akure, Akure 340271, Nigeria; \\ emayok@gmail.com \\ 3 UniSA STEM, Scarce Resources and Circular Economy (ScaRCE), University of South Australia, \\ Adelaide 5001, Australia; Nicholas.Chileshe@unisa.edu.au \\ * Correspondence: Ahmed_17008588@utp.edu.my or A.farouk.kineber@gmail.com
}

Received: 8 October 2020; Accepted: 28 October 2020; Published: 3 November 2020

\begin{abstract}
Value management (VM) has become a useful tool for achieving sustainability in many countries. This paper aims to assess VM implementation and its activities towards achieving sustainable building projects in Egypt. Data were obtained from the literature, followed by a qualitative approach through a semi-structured interview and a quantitative approach via a questionnaire survey. In Cairo and Giza, data were collected from a sample of 200 building professionals using a questionnaire, while exploration of the country's VM activities practice was completed using exploratory factor analysis (EFA), including descriptive statistics such as "frequency analysis" and "measures of central tendencies". The results show that VM awareness was demonstrated by $64 \%$ of the sample, which means that they know about VM. On the other hand, most respondents, $85.3 \%$, did not adopt VM and did not receive any VM training. The results also show, through EFA, that the correlations between these activities show five main components: an information phase, a function phase, a creativity phase, an evaluation phase, and a development/presentation phase. This study will help building professionals to eliminate unwanted costs and enhance project sustainability by adopting VM in building projects in developing countries. Finally, the results of this study will enhance building management through the implementation of VM elements, with a view to ensuring value for money and meeting sustainability goals.
\end{abstract}

Keywords: building projects; sustainability; sustainable construction; value management; exploratory factor analysis; construction management

\section{Introduction}

Building projects significantly influence culture, the environment and the economy over their whole life cycle. Buildings utilize more than $40 \%$ of universal power and energy and represent $30 \%$ of the total greenhouse gas (GHG) emissions in developed and developing nations [1]. Over $40 \%$ of Europe's and the USA's absolute power and energy is consumed via buildings [2,3]. In developing countries, the building field's project sustainability is subservient. These countries have experienced rapid development; therefore, there is no doubt that the building industry provides a crucial role in providing basic living [4]. This field's success indicators are measured by quality, cost, and time of construction projects [5]. The construction industry has experienced significant changes in meeting the developing countries' commercial requirements and goals [6]. It has been reported that the 
majority of the financial procedures of developing countries are still in the process of up-gradation [7]. Building projects in these cultures are frequently faced with various challenges, including failure to meet the required targets, schedule delays, budget over-runs, and insufficient sustainability $[8,9]$. Additionally, efforts to study the social budget of building projects in urban residential fields are still inadequate [10]. Taken altogether, the construction industry does not fulfill the aspirations of their respective government, clients, and sustainability targets in developing nations unlike other sectors like banking and manufacturing [11].

Egypt is a developing country with one of the most extreme examples of hazard marketplaces due to joblessness and the low salary scale of the employed [12]. These problems are a result of currency fluctuations, an absence of occupational selections and restrictions in financing standards [13]. It is also one of the most populated countries in North Africa, with rapid population increases occurring from 1950 to 2020 [14]. It is reported that the projected population by 2020 will be more than five times that of the 1950 population, according to average estimates. Consequently, building project shortages and meeting sustainability requirements represent the most significant and rising challenges facing policymakers in Egypt [15]. This problem puts pressure on the government to meet the residents' demands for adequate housing, with sufficient sustainability [16]. The building market is expected to grow due to population growth and urbanization, and between 2008 and 2013, the Egyptian population increased by $9 \%$ [15]. Moreover, rural urbanization between 2001 and 2012 has increased by $0.9 \%$ [15]. This has stressed the importance of and directed the improvement of "sustainable buildings" that are environmentally friendly and resource-efficient over their development procedures.

Brundtland et al. [17] defined sustainability as "achieving the needs of the current population without compromising future generations' ability to satisfy their own needs". Kibert [18] expressed sustainable construction as building a healthy ecosystem using ecological concepts, and with efficient use of resources. Sustainable construction has commonly been explained as a procedure that initiates before execution and continues after the practical completion of the construction project [19]. Wolstenholme et al. [20] agreed that the building industry should be modernized through implementing effective, integrated, novel, and sustainable building practices. Enhancing sustainability knowledge and understanding at the beginning of a building project is hugely recommended to control its course. Value management (VM) can integrate a sustainable approach at the initial and design stages of project procedures [21]. Society of American Value Engineers (SAVE) [22] recommended that VM is a mechanism that has been confirmed to improve the sustainable value of a project.

VM is a structured, function-oriented, systemic team approach to evaluate the functions, objectives, and costs of a process or facility to maximize its efficiency, by performing the necessary functions defined by customers at the least possible overall expense, coherent with performance criteria [23]. VM studies are frequently organized in the initial stages of a project to accomplish the greatest benefits and resource savings [24]. While costs are the essential objective of VM studies, VM is recognized as a cost-cutting method and a value-improvement technique [25]. The project's budget should not be decreased at the expense of its sustainability and functionality purposes, which would then reduce its value [26]. VM targets to accomplish the anticipated value with lower prices, without compromising the building's quality and performance [27]. VM adoption allows an in-depth evaluation of the objectives and expectations of projects from the customer or investor's perception [28].

Although previous studies have discussed VM benefits, activities, and technological efficiency in several countries, no effort has been made to determine the effects of VM implementation in developing countries. VM methods have not received comparable coverage in the majority of developing countries, including Egypt [29]. It is vital to remember that there is a research gap in this area. There is no formal VM study for the purpose of VM implementation and awareness in Egypt [30]. Subsequently, the implementation of VM standards is vital, as the country experiences low environmentally sustainable projects [31]. Moreover, Egypt had planned to be a country with a prosperous, balanced, and competitive economy. By 2030, the Government of Egypt aims to make Egypt one of the best thirty nations in the world, through the application of various management 
approaches like VM [32]. As a result, there is a need for VM implementation in Egyptian construction projects [33]. It is was hypothesized that there is a concordance on the importance of VM activities in building projects. Therefore, this paper aims to evaluate the application of VM and explore its activities in building projects in developing countries. For this to happen, mixed-method research is proposed for the first time, to explore VM activities in the Egyptian construction industry. The results from this study will be useful to assist decision-makers in succeeding in their building projects by eliminating unwanted costs and enhancing sustainability by implementing VM. As such, the results could be a game-changer in building projects-not only in Egypt but also in developed nations where buildings projects are implemented through a similar style and procedure [34].

\section{VM and the Sustainable Built Environment Industries in Previous Studies}

The subject of sustainability has been stressed by existing studies [35]. Transforming strategic sustainability targets and strategies procedures for projects is a complicated procedure [36] and a balance is essential among the social, economic and environmental aspects of sustainability [35,37]. The emergence of sustainability in the building industry has led to a search for practical ways to infuse this concept into existing working environments [21]. The need for sustainable improvement and the innovative corporate social responsibility ethic implemented through companies are drivers that could also encourage the adoption of VM at the primary strategic phases of building projects [38]. VM is an organized and analytical procedure designed to improve value for money by delivering the required functions of projects at the least cost while also paying attention to sustainability requirements [39]. Contemporary viewpoints, however, indicate a more significant role for VM in the identification, explanation, and confirmation of customer expectations and priorities early in the procurement stage [40]. This view aligns VM typically to the project briefing phase [41], but it is not clear how these are understood by professionals in the built environment.

The VM practice focuses on organized workshops from 4-hours (half a day) to 5 days [42]. The modifications in VM workshop days can be affected by factors such as the VM scope (i.e., size and system of the project, the extent to be objective for VM), and the VM stages/phases to be adopted. The methodological approach differs, for example, the US value engineers society (SAVE), highlights a three-step methodology "pre-study, value study, and post-study". The value study aims to implement six phases of the workshop, that is, information phase; function analysis phase; creative phase; evaluation phase; development phase; and presentation phase [22]. However, of these six phases, information, development, and presentation phases could be performed outside the workshop more efficiently and virtually [40]. While sustainability might not be regularly used in VM studies, sustainability dimensions such as a healthy indoor environment, minimization of waste, energy efficiency, aesthetic influences, user comfort, air and quality of water, and low life-cycle costs are regularly considered [43]. Sustainability thoughts can differ from one VM study to another because of the owners' distinctive objectives, the obligation to construction and execution viewpoints, awareness of the VM team members, and time available for the study [43]. For instance, sustainability principles have been adopted in many UK developments as part of a value management study, such as a sustainable building project in Crianlarich, Startfilan [44]; sustainable residential buildings and services in Stirlingshire; and the Katrine Water Project at Loch Katrine, Scotland [45]. Hayles [46] highlighted that, by encouraging major clients to implement VM concepts, a sustainable procedure to building decision making could be achieved. Al-Yousefi [47] revealed many advantages of handling VM as a framework to encourage and launch sustainability ideologies, such as increasing the effective use of tools and resources, enhancing applications and operational maintenance. Kelly et al. [48] concluded that commitment of multi-disciplinary stakeholder members, organized and formal VM study, sustainable concepts adoption as project objectives and focus on project cost delivery encourages the combination of VM with sustainability. Therefore, adopting sustainability via VM is feasible and advisable [49].

In the past three decades, substantial work has been carried out in VM adoption in the construction industry. However, there is a lack of studies comparing VM's current practice and application by the 
built environment stakeholders; especially in developing countries like Egypt. This study, therefore, explores this gap. The aim of this study therefore is to examine VM activities' understanding and current practice in the built environment with a view to achieving sustainable delivery of building projects.

\section{Research Methods}

The aim of this research is to enhance the sustainable delivery of building projects in the Egyptian construction industry through the adoption of VM. However, this paper is part of bigger research aimed at examining the impact of VM on the overall success of construction projects. The paper explores necessary VM activities require for sustainable delivery of construction projects through EFA analysis. The study adopted exploratory sequential mixed-method research. A mixed-method study was adopted with a view to enhancing the findings of the study for appropriate discussion. [50]. It is confirmed that using mixed methods to explore the same issue will help discover many recurrent patterns or consistent correlations between variables. Figure 1, adopted from Buniya et al. [51], shows the research process for the study. The study commenced with a critical review of previous studies and then qualitative research was performed by interviewing fifteen specialists from the Egyptian construction industry to refine selected activities obtained through previous studies. Validity and reliability tests were thereafter carried out; findings were also discussed while various conclusions and recommendations were discussed. These items are explained in detail in the subsequent sections of the paper. For instance, Section 2 discusses relevant literature while Section 4.1 explains the qualitative aspect of the study where the questionnaire was adopted. The sections for each of the research process items are indicated in Figure 1.

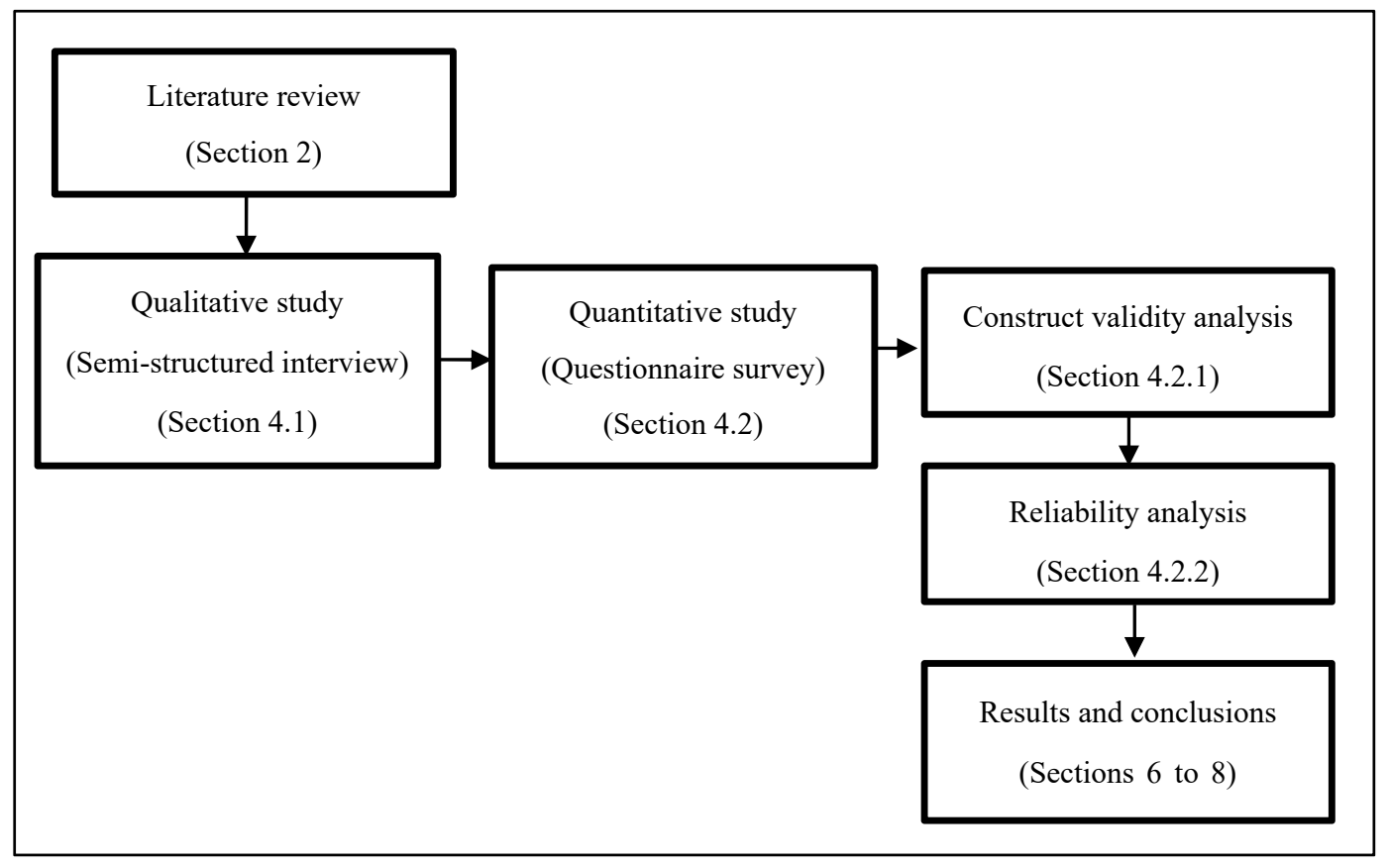

Figure 1. Research flowchart.

\section{Research Process}

\subsection{Qualitative Study (Semi-Structured Interview)}

VM measurement instrument adopted for the study was drawn from several studies in the area of VM adoption and its activities in the construction industry. A qualitative approach through 15 semi-structured interviews was undertaken with industry specialists to understand the activities that may influence VM implementation in building projects through a purposive sampling approach. This approach allows researchers to achieve the research objectives and control the variation levels 
between interviewees [52]. Additionally, while 15 interviews can appear to be moderate samples, Mason [53] reports that the sample size is irrelevant in qualitative research because its value is based on data quality. Many studies agreed that from ten to sixteen interviews were considered adequate [33,54].

In light of the different positions played in building projects, the interviewees' profiles indicated that they possess the required skills from the required organizations to contribute adequately to the study. Furthermore, as shown in Table 1, there is a fair representation of various individuals eligible to be members of the construction value management team. This implies that the interviewees possess the required knowledge and experience to provide meaningful and adequate information for the study [55]. This study adopted the abductive approach, a new approach currently becoming popular among modern researchers [56]. This technique uses previous studies to establish a theoretical basis from which a research methodology and analysis can be developed [57]. In other words, if issues can be described as a set of literature proposals, the definition of a framework is similar to the hypothetical deductive concept [56].

Table 1. Semi-structured interviewees' profile.

\begin{tabular}{|c|c|c|c|c|c|}
\hline No. & Position & Education & Experience & Subdivision & Organization \\
\hline 1 & Director & Ph.D. & 30 & Private & Contractor \\
\hline 2 & Project manager/Professor & Ph.D. & 28 & Government & Owner \\
\hline 3 & Senior Quantity surveyor & M.Sc. & 20 & Government & Contractor \\
\hline 4 & Senior director & B.Sc. & 24 & Private & Owner \\
\hline 5 & $\begin{array}{c}\text { Principle } \\
\text { Consultant/Professor }\end{array}$ & Ph.D. & 40 & $\begin{array}{l}\text { Independent } \\
\text { Consultant }\end{array}$ & Consultant \\
\hline 6 & $\begin{array}{c}\text { Senior project } \\
\text { manager/Associate } \\
\text { Professor }\end{array}$ & Ph.D. & 30 & $\begin{array}{l}\text { Independent } \\
\text { Consultant }\end{array}$ & Consultant \\
\hline 7 & President/Professor & Ph.D. & 35 & $\begin{array}{l}\text { Independent } \\
\text { Consultant }\end{array}$ & Consultant \\
\hline 8 & Architect & M.Sc. & 15 & Government & Owner \\
\hline 9 & $\begin{array}{c}\text { Civil engineer/Associate } \\
\text { Professor }\end{array}$ & Ph.D. & 28 & $\begin{array}{l}\text { Independent } \\
\text { Consultant }\end{array}$ & Consultant \\
\hline 10 & Civil engineer & M.Sc. & 12 & $\begin{array}{l}\text { Independent } \\
\text { Consultant }\end{array}$ & Consultant \\
\hline 11 & Quantity surveyor & B.Sc. & 9 & Private & Owner \\
\hline 12 & Associate Principle & M.Sc. & 25 & $\begin{array}{l}\text { Independent } \\
\text { Consultant }\end{array}$ & Consultant \\
\hline 13 & $\begin{array}{l}\text { Architect/Associate } \\
\text { Professor }\end{array}$ & Ph.D. & 22 & Private sector & Contractor \\
\hline 14 & Cost manager & M.Sc. & 15 & Private & Contractor \\
\hline 15 & Civil engineer & B.Sc. & 10 & Government & Owner \\
\hline
\end{tabular}

Data analysis is to test the framework, enrich it and possibly extend it [57]. In the current study, existing literature was used to develop theoretical frameworks (VM activities) to design new ideas and take advantage of the necessary operating principles to evaluate the existing concepts. The interviews that follow enrich the framework and extend it. More so, the abduction approach was followed so that the evidence and current theories could be re-examined and analyzed in a local context. Consequently, VM activities were modified and categorized.

\subsection{Quantitative Study (Questionnaire Survey)}

To validate VM's categorizations and its activities obtained from the semi-structured interview, a pilot study was subsequently adopted before the main study, poised to examine the phases of VM and its activities using a questionnaire survey. This questionnaire survey helped to evaluate the following aspects: (1) Behaviors, opinions, and organizational norms, as well as (2) The link among various variables, primarily cause-and-effect relationships [58]. The questionnaire was subjected to 
a pilot test as suggested by Fellows and Liu [59] to check the questionnaire's intelligibility, ease of response, and clearness as well as to determine the required time for the survey. The pilot study focused on the perceptions and involvement of developers, consultants, and clients in the delivery of construction projects.

\subsubsection{Construct Validity Analysis}

The Confirmatory Factor Analysis (CFA) and Exploratory Factor Analysis (EFA) techniques are normally used for factor analysis. In this study, CFA was used for evaluating the structure underlying the adopted variables with a view to properly test the proposed hypotheses. On the other hand, EFA was used to gather information about the relationship among variables and reduce the variables into a few underlying structures. It is one of the functions built into the Statistical Package for the Social Sciences (SPSS) [60].

In the current study, the main multivariate analysis method, that is, EFA, was employed to explore the primary constructs of VM phases after categorizing the same from the interviews. It was used to assess the constructs' validity by evaluating the adequacy of the measurement items of individual constructs (i.e., measurement models) regarding their un-dimensionality, reliability, and validity. It is important to note that Principal Component Analysis (PCA) was selected over Principal Axis Factoring (PAF), image factoring, maximum probability, and alpha factoring since PCA is more accurate and less conceptually complex [61]. PCA is advocated when there is no prior theory or model and when preliminary solutions are found in EFA [60]. Thompson [62] reported that, in many statistical programs, PCA is the default form and is thus most widely used in EFA. The varimax rotation method was preferred over the direct oblimin or Promax because varimax's rotation attempts to optimize load dispersion between variables. Varimax is also suitable for simple factor analysis and is an excellent general approach that simplifies the clarification of factors [63]. More so, the number of participants can be used as a representative sample within acceptable ranges [64]. The 21 variables as well as 200 participants used in the current study, are considered suitable for factor analysis. It is vital to highlight that the sample size and methodology adopted for this research is similar to the study by Kim et al. [65] with 100participants; Luvara and Mwemezi [66] with 231 participants; and Shen and Liu [67] with 200 participants.

\subsubsection{Reliability Analysis}

A research method's validity and reliability are essential and must be taken into account to cover and ensure accurate results are obtained [68]. However, face and content validity are two traditional validity measures used to assess the extent to which the research instrument elements are significant and are reflective of a targeted research structure [69]. Twelve research experts from both the academic and the building sector were randomly chosen to validate the research instrument. According to Sushil and Verma [70], face validity is evaluated by having experts check the contents of the test to ensure that the items and questions are adequate. Furthermore, Cronbach's $\alpha$ test was used to check the research instrument's reliability.

\section{Data Collection}

\subsection{Semi-Structured Interviews}

The contributors were selected according to their years of practice, experience, education, and type of organization, as outlined in Table 1. Information in Table 1 also indicates that the respondents possess extensive knowledge of the construction industry.

Each interview lasted approximately $40-90 \mathrm{~min}$ and was recorded with the permission of the interviewee. The research followed a semi-structured interview method for the interviewees to stay concentrated and focused on VM activities [71]. The confirmation and checking procedures were 
undertaken between iterative interviews and data analysis [72]. This combined process is like the participation checks and validation as noted and adopted in the previous studies [71].

The interview method consisted of a variety of open questions in accordance with the study's objectives. The instrument of the interview was divided into four sections, that is, background information about the experts, knowledge, application and implementation of VM in the organizations, VM activities in the construction and building projects, benefits of implementing VM in the construction industry and factors affecting the adoption of VM for project sustainability.

To analyze the interview transcripts, a content analysis technique was used. Transcription is considered the first step toward the descriptive process of the results in which the interview contents are recalled and transformed into text [73]. As a result, interviewed experts argued that a more formal system should guide the implementation of the VM in projects and categorized VM phases activities under five phases, as shown in Table 2. Moreover, several activities were modified, and three activities were added to the list, as indicated in Table 2. The updated and added activities were used to develop the questionnaire.

\subsection{Questionnaire Survey}

Following the interview with experts, a pilot study via EFA analysis was conducted to check the new constructs as obtained from the interview sessions, with a view to possibly modify the content and design of the main questionnaire.

For this research, a stratified sampling method of the three major building boundaries in Giza and Cairo was adopted. Sharma [74] approved that the significant benefits of stratified sampling are as follows: (1) decreasing the biases in the choosing of the sample cases, which indicates that the sample will have a highly representative description of the population under study; (2) allow simplification of samples to the population (i.e., statistical inferences), since the selected cases are chosen based on a probabilistic approach, and this is a significant benefit because the generalization appears externally valid; and (3) to ensure that enough sampling points are used to support the independent study of all strata. As a result, a pre-qualification analysis with the various organizations was performed through telephone calls. Over 280 companies were generated in the screening study, but only 215 companies agreed to participate. This test also reviewed positions, addresses, and assurances that the companies selected have reached their five-year survival level. The selected companies are with 9 to 250 staff, self-employed, non-foreign corporations and they were established between 1994 and 2010. This is to overcome any impact from the parent group's international policy [75].

For the number of samples required for EFA analysis, there is no consensus among previous studies of a larger survey has been recommended $[64,76]$. Furthermore, the factor analysis is acceptable for 20-50 elements as factors are properly analyzed when the number of elements is within this number [77]. However, much literature has found that fewer variables may be studied if the sample size is large enough [29,78]. Consequently, in this study, 200 questionnaires were distributed but only 150 were returned filled and fit for analysis, this represents about $75 \%$, which is well within acceptable level [64]. Some of the observations from the pilot study include improper use of dot lines, inaccurate counting of variables, spelling errors, and orthographic errors. Such views, observations, recommendations, and corrections were reported and included in the final draft of the final survey instruments.

The first section of the data collection was to collect demographic information of respondents and their projects. In the second section, VM adoption activities were rating using a 5-point Likert scale with one $=$ very low, two $=$ low, three $=$ average four $=$ high, and, five $=$ very high as adopted in similar studies regarding the implementation of VM $[79,80]$. The activities identified from the literature review and the expert interviews are listed in Table 2. Finally, for the Egyptian building projects, 21 possible VM adoption activities were identified; hence, the questionnaire was validated on a face-to-face basis. The Cronbach $\alpha$ analysis was also used to evaluate the research tool's reliability, following EFA's generation. 
Table 2. Factors and associated literature.

\begin{tabular}{|c|c|c|c|}
\hline Group Names & Code & Activity Name & References \\
\hline \multirow{5}{*}{ Information phase } & VM.IP1 & Carry out a site visit & [81] \\
\hline & VM.IP2 & $\begin{array}{l}\text { Collect related historical information on the } \\
\text { proposed project }\end{array}$ & [82] \\
\hline & VM.IP3 & Establish the time period and scope of the project & [81] \\
\hline & VM.IP4 & Involve stakeholders in the initial stage of the project; & [83] \\
\hline & VM.IP5 & $\begin{array}{l}\text { Involve and allocate duties to construction specialists } \\
\text { at the initial stage of the project; }\end{array}$ & [81] \\
\hline \multirow{7}{*}{ Function phase } & VM.IP6 & Clarify relevant details and limitations of the project & [82] \\
\hline & VM.IP7 & Share project knowledge between professionals & [83] \\
\hline & VM.IP8 & Identify the project's high-cost areas & [84] \\
\hline & VM.FP1 & $\begin{array}{l}\text { Make client express the scale and predictions of the } \\
\text { project explicitly }\end{array}$ & [84] \\
\hline & VM.FP2 & Presentation by stakeholders of project restrictions & [83] \\
\hline & VM.FP3 & $\begin{array}{c}\text { Express and understand the goals and roles } \\
\text { of the project }\end{array}$ & [81] \\
\hline & VM.FP4 & $\begin{array}{l}\text { Create and identify functions with their related costs } \\
\text { into essential and secondary objects }\end{array}$ & [82] \\
\hline \multirow[b]{2}{*}{ Evaluation phase } & VM.EP1 & Estimate the cost of each alternate life cycle & Interview \\
\hline & VM.EP2 & $\begin{array}{l}\text { Assess brainstormed alternatives to fulfill the } \\
\text { desired functions }\end{array}$ & [84] \\
\hline \multirow{3}{*}{ Creativity phase } & VM.EP3 & Investigate the alternative assessment criterion & Interview \\
\hline & VM.CP1 & $\begin{array}{l}\text { Brainstorm on solutions and concepts to accomplish } \\
\text { the desired functions and costs. }\end{array}$ & [82] \\
\hline & VM.CP2 & $\begin{array}{l}\text { Categorize brainstormed session alternatives and } \\
\text { suggestions into realistically appropriate to be adopted }\end{array}$ & [82] \\
\hline \multirow{4}{*}{$\begin{array}{l}\text { Development/presentation } \\
\text { phase }\end{array}$} & VM.CP3 & $\begin{array}{c}\text { Defining the project procurement and contract } \\
\text { strategy approach }\end{array}$ & [84] \\
\hline & VM.DP1 & Establish a short-term alternative action plan & [84] \\
\hline & VM.DP2 & Meet and request a review of the action plan & [82] \\
\hline & VM.DP3 & Track a VM output action plan & Interview \\
\hline
\end{tabular}

\section{Results and Findings}

\subsection{Respondents' Characteristics and Demographic Profiles}

The authors classified the participants in this research based on their years of work experience, professionalism, present positions, level of education, and organizational function, as shown in Table 3. Regarding the profession of respondents, civil engineers accounted for the highest number $(30.7 \%)$, followed by Architect (26.7\%) while the least are Quantity Surveyors. Findings of the present position indicated that the Site Engineer had the maximum frequency (36.0\%) followed by the Manager (30.0\%), while the least frequency was observed for the director (6.0\%). For the organization, $38 \%$ are from clients' organizations followed by contractors and consultants. For respondent's qualifications, 10.7\%, $47.3 \%$, and $23.3 \%$ are Bachelor, Master, and Ph.D. degree holders respectively. Table 3 also shows that around $18.7 \%$ of respondents had worked from one year to less than five years. Respondents with work experience ranging from 5 to 10 years, 11 to 15 years, and more than 25 years were approximately $16.0 \%, 27.3 \%$ and $15.3 \%$ respectively. This indicates that the participants in this study are experienced to provide the required information. 
Table 3. Demographic characteristic frequency distribution.

\begin{tabular}{|c|c|c|c|}
\hline Variable & Characteristics & Number of Respondents & $(\%)$ \\
\hline \multirow{6}{*}{ Work experience (Years) } & Less than five & 28 & 18.7 \\
\hline & $5-10$ & 24 & 16.0 \\
\hline & $11-15$ & 41 & 27.3 \\
\hline & $16-25$ & 34 & 22.7 \\
\hline & More than 25 & 23 & 15.3 \\
\hline & Architect & 40 & 26.7 \\
\hline \multirow{4}{*}{ Professional field } & Civil Engineer & 46 & 30.7 \\
\hline & Electrical Engineer & 28 & 18.7 \\
\hline & Mechanical Engineer & 24 & 16.0 \\
\hline & Quantity surveying & 12 & 8.0 \\
\hline \multirow{5}{*}{ Current position } & Director & 9 & 6.0 \\
\hline & Senior Manager & 14 & 9.3 \\
\hline & Manager & 45 & 30.0 \\
\hline & Design Engineer & 28 & 18.7 \\
\hline & Site Engineer & 54 & 36.0 \\
\hline \multirow{6}{*}{ Educational level } & Diploma & 9 & 6.0 \\
\hline & Bachelor's degree & 16 & 10.7 \\
\hline & M.Sc. & 71 & 47.3 \\
\hline & Ph.D. & 35 & 23.3 \\
\hline & Others & 28 & 18.7 \\
\hline & Client & 57 & 38.0 \\
\hline \multirow[t]{2}{*}{ Organization function } & Consultant & 43 & 28.7 \\
\hline & Contractor & 50 & 33.3 \\
\hline \multirow{2}{*}{$\begin{array}{l}\text { VM workshop adopting and } \\
\text { attending }\end{array}$} & Yes & 22 & 14.7 \\
\hline & No & 128 & 85.3 \\
\hline \multirow{3}{*}{ Formal training on VM } & Yes & 12 & 8.0 \\
\hline & No & 138 & 92.0 \\
\hline & Totally Familiar & 2 & 1.3 \\
\hline \multirow{3}{*}{ Awareness } & Familiar & 94 & 62.7 \\
\hline & Moderately familiar & 28 & 18.7 \\
\hline & Not familiar & 10 & 6.7 \\
\hline \multirow{3}{*}{ Perception } & Technique & 16 & 10.7 \\
\hline & A concept & 68 & 45.3 \\
\hline & A profession & 66 & 44.0 \\
\hline
\end{tabular}

\subsection{Level of Awareness and Implementation of VM in the Egyptian Construction Industry}

This research examined participants' understanding and awareness of the VM method implementation, as showed in Table 3. Observation of the result illustrates that $45.3 \%$ of respondents considered the perception of value management or value engineering as a concept while $44.0 \%$ of the respondents considered it as a profession. This finding is consistent with the finding of awareness of VM or value engineering where $62.7 \%$ of the respondents were familiar and $1.3 \%$ were totally familiar with the practice of VM. In general, the respondents had moderate VM awareness, with a knowledge level of $64.7 \%$, slightly higher than the $50 \%$ average, which indicates an adequate awareness level between stakeholders. On the other hand, most of the respondents (about $85.3 \%$ ) did not attend a VM workshop or received a formal VM workshop, 92.0\% did not receive any VM training in respect to adopting and participating in VM workshops. This implies that these corporations did not adopt the VM. Most companies investigated reported that they do not use VM because of a variety of reasons like lack of cost and low level of awareness.

\subsection{EFA for VM Implementation Activities}

This study's primary aim is to explore the VM activities in the building projects, and this was achieved through EFA analysis. However, the test of data normality is vital before launching the EFA study. In the current study, the normality of data was measured as an elementary assumption, and the 
results of the normality test for VM activities are shown in Table 4. Byrne [85] concluded that if the kurtosis result is between -7 to +7 and skewness results are between -2 to +2 , the data are regarded as normal. As shown in Table 4, the skewness ranged from -1.51 to -0.68 , and the kurtosis ranged from 0.05 to 1.66 , which indicates that all variables are normally distributed.

Table 4. Result of Normality Test.

\begin{tabular}{ccccc}
\hline Variable & Skewness & Std. Error & Kurtosis & Std. Error \\
\hline Information phase & -1.51 & 0.17 & 1.66 & 0.33 \\
Function phase & -1.15 & 0.17 & 0.76 & 0.33 \\
Evaluation phase & -0.86 & 0.17 & 0.36 & 0.33 \\
Creativity phase & -0.90 & 0.17 & 0.19 & 0.33 \\
Development and presentation phase & -0.68 & 0.17 & 0.05 & 0.33 \\
\hline
\end{tabular}

EFA was used to evaluate the structure of the factor across twenty-one VM implementation activities. Many well-known constraints for the factorability of a connection were used. KMO was adopted to assess factor homogeneity and is popularly adopted to evaluate whether the variables' partial correlations are minimum [86]. Table 5 illustrates that the sampling adequacy measure of $\mathrm{KMO}$ was 0.755 , which is exceeding the suggested value of 0.6, and Bartlett's Test of Sphericity was significant $\left(x^{2}(210)=1204.837, p<0.05\right)[64,87,88]$.

Table 5. Kaiser-Meyer-Olkin (KMO) and Bartlett's test result related to value management (VM) activities.

\begin{tabular}{lcc}
\hline \multicolumn{3}{c}{ KMO and Bartlett's Test } \\
\hline Kaiser-Meyer-Olkin Measure of Sampling Adequacy & $\mathbf{0 . 7 5 5}$ \\
\hline & Approx. Chi-Square & 1254.261 \\
Bartlett's Test of Sphericity & Df & 210 \\
& Sig. & 0.000 \\
\hline
\end{tabular}

The anti-image correlation matrix diagonals were just above 0.5 indicating that all the elements can be included in the factor analysis. Initial communalities were meant to assess the variance in every activity reflected by all components, and the slight values $(<0.3)$ show variables that do not appropriately fit with the factor solution. Consequently, the results here show that every part of the initial communities exceeded the threshold, and all loadings were more than 0.5 as indicated in Table 6 .

Table 6. Communalities of VM activities.

\begin{tabular}{cccc}
\hline Item & Communalities & Item & Communalities \\
\hline VM.IP1 & 0.626 & VM.FP4 & 0.731 \\
VM.IP2 & 0.700 & VM.EP1 & 0.728 \\
VM.IP3 & 0.416 & VM.EP2 & 0.698 \\
VM.IP4 & 0.669 & VM.EP3 & 0.758 \\
VM.IP5 & 0.790 & VM.CP1 & 0.694 \\
VM.IP6 & 0.630 & VM.CP2 & 0.714 \\
VM.IP7 & 0.647 & VM.CP3 & 0.763 \\
VM.IP8 & 0.483 & VM.DP1 & 0.698 \\
VM.FP1 & 0.670 & VM.DP2 & 0.660 \\
VM.FP2 & 0.768 & VM.DP3 & 0.715 \\
VM.FP3 & 0.723 & & \\
\hline
\end{tabular}

The findings of the EFA for VM activities resulted in only six factors with values greater than 1 for eigenvalues with a total variance of $68.03 \%$. Findings from Varimax rotation demonstrated that $17.66 \%$ of the variance was explained by the first factor (information phase) and $13.18 \%$ of the 
variance by the second factor (function phase). The third component contained another subscale called the evaluation phase, which explained $11.04 \%$ of the variance, followed by component four (creativity phase), which explained $10.25 \%$ of the total variance. The fifth component, which relates to the development and presentation phase, was able to explain $9.75 \%$ of the total variance. It is important to note that just one item (VM.IP5) was eliminated. It was included as the last component and initially part of the information phase. Therefore, for this study, only five extraction components were found adequate. Pallant [87], therefore, proposed that the screen plot and matrix should be analyzed objectively to assess the components (factors) that are extracted and determined. A shift (or Elbow) in plot shape is detected when examining the screen plot, and only sections above this level are kept. Figure 2 further reveals that the six aspects are modified.

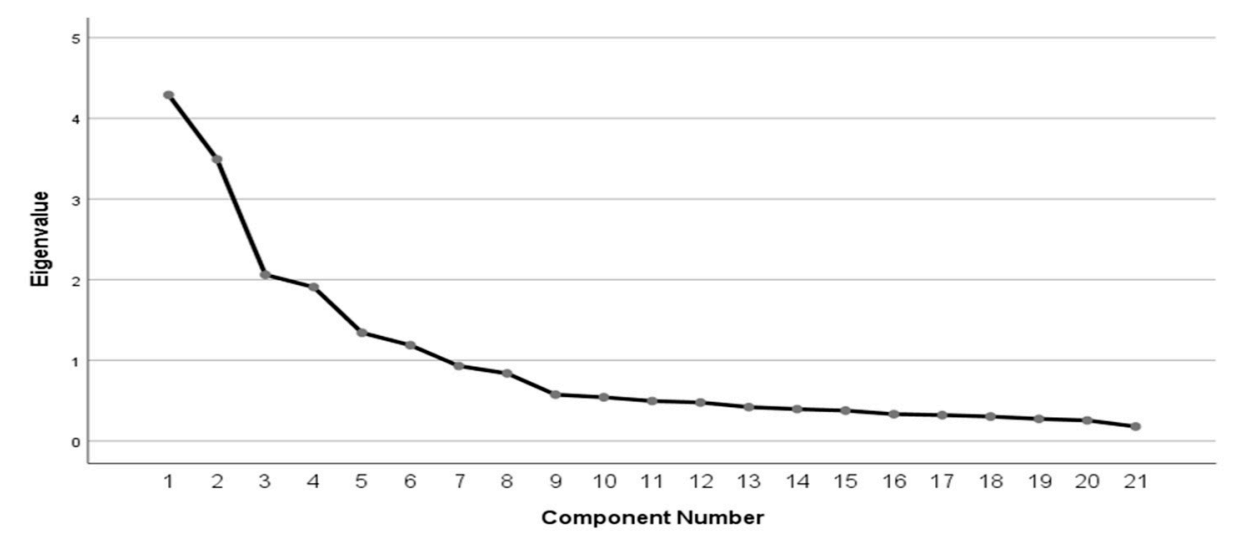

Figure 2. Scree plot result for VM activities components.

\subsection{Reliability Analysis}

For the factors extracted through EFA, the reliability statistics were determined. Table 7 indicates the results. The value of the Cronbach alpha becomes more acceptable as it tends towards 1.0 [89] Consequently as shown in Table 7, all VM activities have appropriate reliability since alpha Cronbach levels are greater than 0.6 [61].

Table 7. Reliability statistics for extracted factors (Cronbach's alpha).

\begin{tabular}{ccc}
\hline Factor (VM Phases) & No. of Variables & Cronbach's Alpha \\
\hline Information Phase & 7 & 0.827 \\
Function Phase & 4 & 0.835 \\
Creativity Phase & 3 & 0.771 \\
Evaluation Phase & 3 & 0.799 \\
Development and Presentation Phases & 3 & 0.620 \\
\hline
\end{tabular}

\section{Discussion}

Building projects impact the economy, society, and the environment over their whole life cycles [90], hence the link with sustainability. To accomplish the building project sustainability, there is a need for techniques that provide a clear vision of the projects' situation and realize other project objectives [10]. VM has been recognized as having the possibility to incorporate sustainability for building projects because it utilizes various knowledge resources, significant procedures, facilitated environment, strategic timing, and stakeholders and professional disciplines [49]. However, studies on the implementation of VM have focused on factors influencing the effective implementation of VM. Nevertheless, no study has measured or assessed the activities and elements that encourage the adoption of VM for sustainable building projects [91], particularly in Egypt. 


\subsection{Identify the Level of VM Awareness}

Awareness of VM and its processing in construction projects significantly influence top management's decision to implement VM. Implementing VM is a complex activity requiring numerous details from different parties, but knowledge of the process can help overcome implementation challenges. From this study, it is evident that $64 \%$ of the respondents have adequate knowledge of $\mathrm{VM}$, which means that they have a moderate amount of knowledge regarding VM. This research is contrary to the observation of Khodeir and El Ghandour [15] that about $51.6 \%$ of their respondents have light-sized knowledge of VM. The reasons can be due to the difference between the findings of both studies. Khodeir and El Ghandour [15] only covered thirty-five participants, the current study examines the topic more widely by assessing building experts' knowledge and collecting 150 questionnaires in the country's two largest regions (Cairo and Giza). Therefore, the higher the number of people covered, the greater the chances of more professionals that are aware of the subject.

\subsection{Factor Analysis Results}

Five phases of VM in Egyptian building projects were extracted through EFA. The activities executed are extracted under information, function, creativity, evaluation, and development/presentation phases. This finding did not match with the study of Tanko et al. [92] which was carried out in the Nigerian construction industry. Their findings show that the VM is extracted under three phases, that is, information/function phase, creativity/evaluation and development/presentation phase. These findings necessitate a need to enhance the application of VM in developing countries since the professionals in those countries did not consider VM phases according to VM standard generated by SAVE [22]. The extracted phases in this research are hereby discussed:

\subsubsection{Information Phase}

The first principal component is the information phase, which contains seven items, and accounts for $17.66 \%$ of the variance explained. This includes activities such as clarify project background information and constraints (0.769), involving clients and stakeholders at the early phase of the project (0.764), site visitation (0.732), share project information between stakeholders and professionals, identify high-cost areas of the project (0.699), involving and assigning duties to construction professionals at the early phase of the project (0.672), defining the time frame and scope of the project $(0.612)$, collecting related background information on the suggested project (0.600). It is crucial for the exercise of VM that the information phase supports and embraces the adoption of VM. Every VM analysis consists of three types of contributors: decision-makers (owners or owners' representatives), VM team leader (facilitators), and team members [93]. At this stage of the workshop, information sharing is vital, and clients and end-users should obviously and explicitly state the scope, aims, requirements, and anticipations of their planned projects. The responsibility played by every member can provide positively towards the improvement of sustainability [94]. Methods for procurement, duration of projects, environment, and performance are also set out here by these participants. Furthermore, numerous green alternatives were combined into the early design phase in the information phase [49], and clients are expected to inform their objectives. Leung and Liu [95] reported that project objectives influence the VM participants' behavior and the outcome. Additionally, the VM team leader holds a strategic plan to enhance sustainability knowledge and awareness [96]. Communication among clients and VM facilitators increases the chance to motivate owners to commit to sustainability [94].

Consequently, details and information on the context, design, projected costs, and limitations of the project are provided [97]. An inquiry by Mohamad Ramly and Shen [84] revealed that, at this point, construction workers, such as the facilitator's team, provided essential information on their fields. However, different participants may also have identified limitations to their project [98]. 


\subsubsection{Function Phase}

The second principal component, which is the function phase comprised four items and accounted for $13.178 \%$ of the variance explained. It includes activities such as presenting project restrictions and limitations to stakeholders (0.849), creating and classifying functions/items as basic and secondary items with their associated costs (0.812), expressing and understanding the aims and functions of the project (0.802), making the client express clearly the scope and anticipations of the project (0.710). It is important to note that the most critical part of this phase is a logical approach that defines and fulfills the criteria, needs, aims, and anticipated goals of the undertaking. Moreover, four variables for the function phase, namely, mission, space, elements, and shape, will be investigated [99]. Regarding the task, the phase is concentrated on how the sponsor, owner, client, and other main parties to the project primarily view or distinguish a particular task [100]. This step aims to create, identify, and categorize primary and secondary functions [84]. Team members are encouraged during this phase to write down the buildings' functions, which can still be applicable for the next 50 years [90]. The basic and secondary functions with their associated costs are defined and categorized in this way in order to comprehend the sustainable aspects of the project. In the hierarchical function structure known as the functional tree diagram, project functions are defined, analyzed, and the main objective of the process is to recognize the project through the project functions [82]. Furthermore, through this diagram, the critical building objectives and functions established by the owner have been involved in this stage, and the sustainability of the building might itself be an essential aim and function [90]. Sustainability dimensions would be an essential element of the project's aims and functions [49]. Additionally, the study demonstrated that the dimensions of sustainability, such as user comfort, environmental influence and impact, accessibility, society, and life cycle costs, are integrated in the VM decision matrix [42].

\subsubsection{Evaluation Phase}

The third principal component is the phase of evaluation, which consists of three items, and accounts for $10.253 \%$ of the variance explained. It consists of activities such as estimating the total life-cycle cost of each alternative (0.815), investigating the criteria for assessing alternatives (0.778), and evaluating brainstormed alternatives to achieve the desired functions/elements (0.765). Therefore, the VM team must be interdisciplinary in assessing all alternatives during this VM workshop phase to achieve the project's sustainable objective. At this stage, the proposals made are analyzed and evaluated for each of the suggestions and ideas identified in the previous stage (creative stage). A review, assessment, and short-listing are carried out at this stage and to examine less promising ideas, it is necessary to assess each idea against functional requirements [101]. This is supported by the conclusion of Mohamad Ramly and Shen [84] that further testing of proposals and suggestions is best performed to determine how to achieve the project's desired goals and sustainable objectives.

\subsubsection{Creativity Phase}

The fourth principal component is the creativity phase. It consists of three items and accounts for $11.041 \%$ of the total variance. It includes: creating brainstorm alternatives and ideas to achieve the desired functions/elements and related costs (0.801); description of the procurement and contract strategy of the project (0.811) and categorizing the alternatives from the brainstormed session as feasible to be adopted (0.797). It could be noted that ideas are produced and created during the creative stage to fulfill the necessary and preferred functions of a practical tree structure. The members of the VM Workshop team investigate, explore, generates, and tests alternative methods and ways in which tasks are performed throughout these processes [102]. Innovative approaches and techniques, including brainstorming, Synectic, and side thinking, are being applied at this level. The VM facilitator must create a positive environment by ensuring that criticism and repression among VM team members are not possible. Through the creativity phase, the team member can have an excellent opportunity 
to achieve their objective by enhancing innovation ideas. Innovation is one of the highest drivers that could be sustained by the practical approach to improve resource [103]. Moreover, economic and investment sustainability must not be disconnected from community and environmental sustainability in recommending alternatives, solutions, and ideas [90].

\subsubsection{Development and Presentation Phase}

The final primary component, which comprises three items is the development and presentation phase. It is not surprising that the major activity of the phase as obtained from the EFA analysis is that Egypt's professionals did not comply with the VM standards. This combined phase represents $9.748 \%$ of the variance explained. It includes activities such as the generate an action plan on short-listed alternatives (0.811), the follow-up of an action plan on VM output (0.786), and the holding and presentation of an action plan review meeting (0.783), The members of the VM team are responsible for generating short-listed proposals and suggestions. The team preparations, manufacturers, and producers are sketches, descriptions/materials, drawings, specifications, and details as structured VM proposals. Each brief concept is regarded as a feasible, practical, and realistic solution. This step deals with all the drawbacks, benefits, and potential of the concepts and ideas in the guidelines, estimates, and cost of life-cycles measurements. Moreover, at this point, the strategic plan involves each part or function of the development phase. The finding is supported by Oke and Aigbavboa [100] where the development phase was noted to be a crucial step of the VM study and that consideration should be given to ensure that the development and presentation phases are carefully investigated and considered. On the other hand, some authors recommended presentation as the last step of VM. However, this phase's purpose is to send these suggestions to the body that authorized the study as a way of minimalist-feedback [100].

\subsection{VM Activities Implementation for Building Sustainable Success}

Recent building developments have brought more effective and sustainable methods, specialized techniques, and materials [104]. Building direction in the construction industry requires substantial and sustainable development [105]. However, measuring sustainability and performance during usage is becoming increasingly relevant [106]. The strategies to incorporate the concept of sustainable development must be established [107]. Moreover, VM can perform an effective method for achieving building sustainability. This study evaluated VM activities through EFA analysis to suggest VM implementation activities and stages, which can lead to sustainable delivery of building projects. VM study allowed sustainability principles to be included in the conceptual and initial design phases [38]. Through VM study, alternatives are anticipated to promote a healthy and safe ecosystem for the residents [108]. Additionally, VM offers multidisciplinary professionals' chances to focus on issues and matters regarding community, society and the environment $[33,90]$ and effectively enhance sustainability concepts during the life cycle of building projects [90]. The conventional way of considering project success is the so-called iron-triangle of time, cost, and quality, which are frequently reviled in the late decades [109]. Thus, by implementing VM, building companies can balance time, expense, and quality as VM reduces costs, but not at the sacrifice of benefits [110]. Kelly and Male [111] suggested that time measured within the sustainable value system is part of the project's success, and VM can achieve the optimum project time. For instance, in the roadway field, Atabay and Galipogullari [112] used VM as a sustainable tool for saving around 12 months of project time. These results figures amount to $6 \%$ of the total budget and $17 \%$ of the schedule. Not surprising that, in the marine construction field, Tang and Bittner [113] confirmed that VM uses as a useful technique for improving the quality. Moreover, cost and financial sustainability can be targeted in building projects by adopting VM. Lin et al. [114] said that VM is commonly used as a supportive method to address challenges, such as limited financial resources and strict planning in the building industry, as financial analysis represents the primary method for evaluating a company's sustainable improvement and value creation [115]. VM provides sustainability to be included in a 
construction project $[21,116]$. In the sustainability sense of construction firms, it was found that they face several obstacles as they mature and have a positive social, environmental and economic impact [117]. These firms should also search for swift and new means of sustaining customer confidence [107]. The proposed VM activities give these companies practitioners the opportunity to take a good decision for achieving their company's success. These decisions are able to have a long-term effect on corporate practices [118]. Moreover, VM activities could be applied to the extent of traditional capital, operating costs, and the project's duration to expose customer value systems. These companies can only pay attention to sustainability aspects if the value created exceeds the damage caused [119]. Achievements of success by enterprises and their competence to enhance company value over a long time depend on having an effective business model [120], and this model can be achieved through the adoption of VM activities.

\section{Conclusions}

Construction projects, especially in developing countries like Egypt, are characterized by low quality and are not delivered in accordance with sustainable principles. This research showed that $\mathrm{VM}$ is a vital option to address this threat. It was hypothesized that the VM activities implementation is crucial for building professionals to achieve their sustainable goals. To examine this hypothesis, mixed methods research was conducted through a semi-structured interview of fifteen experts and a questionnaire survey. The study collectively deduced that the level of implementation of VM in building projects is relatively poor. The study also showed that building participants in Egypt have reasonable awareness (67.7 percent), and the majority of participants viewed VM as a concept. This indicates that the challenge of VM in the Egyptian construction industry is not of awareness but that of adoption. From the questionnaire analysis through EFA, the study shows that information; function, creativity, evaluation, and development/presentation phases are classified as five phases of VM adoption in Egyptian building projects The study investigated the new activities generated by the experts through the adoption of a semi-structured interview, which was not mentioned in the previous studies. These include estimating total life-cycle costs for each alternative, research evaluation criteria for alternatives and follow up an action plan for VM output. The EFA analysis also leads to the removal of one activity, that is, involve and assign responsibilities to construction professionals at the initial stage of the project. To this end, VM activities are essential for the sustainable delivery of building projects. The study results can guide policymakers and top managers in building projects to systematically understand the relative importance of VM activities and efficient subsequent implementation. Furthermore, the study can support developing countries to consider VM implementation for achieving their overall sustainable success.

Author Contributions: A.F.K. initiated the research project, carried out the mixed methods empirical research, and drafted the manuscript. I.O. supervised the project and provided feedback on the manuscript drafts. A.E.O. supervised the project and provided feedback on the manuscript drafts. N.C. provided feedback on the manuscript drafts. M.K.B. provided feedback on the manuscript drafts. All authors have read and agreed to the published version of the manuscript.

Funding: This research received no external funding.

Acknowledgments: The authors would like to express their utmost gratitude to FRGS grant Ministry of Higher Education Malaysia for supporting this research and Universiti Teknologi PETRONAS, 32610 Seri Iskandar, Perak, Malaysia.

Conflicts of Interest: The author declares no conflict of interest. 


\section{Abbreviations}

The following abbreviations are used in this manuscript:

MDPI Multidisciplinary Digital Publishing Institute

VM Value Management

EFA Exploratory Factor Analysis

GHG Green House Gas emissions

CFA Confirmatory Factor Analysis

SPSS Statistical Package for the Social Sciences

PCA Principal Component Analysis

PAF Principal Axis Factoring

\section{References}

1. Sbci, U. Buildings and Climate Change: Summary for Decision-Makers; United Nations Environmental Programme, Sustainable Buildings and Climate Initiative: Paris, France, 2009; pp. 1-62.

2. DoE, U. Energy Efficiency Trends in Residential and Commercial Buildings; US Department of Energy: Washington, DC, USA, 2008. Available online: http://apps1.eere.energy.gov/buildings/publications/pdfs/corporate/bt_ stateindustry.pdf (accessed on 28 October 2020).

3. Atanasiu, B.; Attia, S. Principles for nearly zero-energy buildings: Paving the way for effective implementation of policy requirements. In Principles for Nearly Zero-Energy Buildings: Paving the Way for Effective Implementation of Policy Requirements; Buildings Performance Institute Europe (BPIE): Brussels, Belgium, 2011; p. 124.

4. Durdyev, S.; Ismail, S.; Ihtiyar, A.; Bakar, N.F.S.A.; Darko, A. A partial least squares structural equation modeling (PLS-SEM) of barriers to sustainable construction in Malaysia. J. Clean. Prod. 2018, 204, 564-572. [CrossRef]

5. Yaseen, Z.M.; Ali, Z.H.; Salih, S.Q.; Al-Ansari, N. Prediction of risk delay in construction projects using a hybrid artificial intelligence model. Sustainability 2020, 12, 1514. [CrossRef]

6. Mousa, A. A Business approach for transformation to sustainable construction: An implementation on a developing country. Resour. Conserv. Recycl. 2015, 101, 9-19. [CrossRef]

7. Fang, Z.; Gao, X.; Sun, C. Do financial development, urbanization and trade affect environmental quality? Evidence from China. J. Clean. Prod. 2020, 120892. [CrossRef]

8. Kissi, E.; Boateng, E.; Adjei-Kumi, T. Strategies for implementing value management in the construction industry of Ghana. In Proceedings of the DII-2015 Conference on Infrastructure Development and Investment Strategies for Africa, Livingstone, Zambia, 16-18 September 2015; pp. 255-267.

9. Adeyemi, L.A.; Idoko, M. Developing Local Capacity For Project Management-Key To Social And Business Transformation In Developing Countries. In Proceedings of the PMI ${ }^{\circledR}$ Global Congress 2008-EMEA, St. Julian's, Malta, 19-21 May 2008; Project Management Institute: Newtown Square, PA, USA, 2008.

10. Maceika, A.; Bugajev, A.; Šostak, O.R. The Modelling of Roof Installation Projects Using Decision Trees and the AHP Method. Sustainability 2020, 12, 59. [CrossRef]

11. Jekale, W. Performance for Public Construction Projects in Developing Countries: Federal Road and Educational Building Projects in Ethiopia; Norwegian University of Science \& Technology: Trondheim, Norway, 2004.

12. Barakat, M.S.; Naayem, J.H.; Baba, S.S.; Kanso, F.A.; Borgi, S.F.; Arabian, G.H.; Nahlawi, F.N. Egypt Economic Report: Between the Recovery of the Domestic Economy and the Burden of External Sector Challenges. Available online: http://www.bankaudigroup.com (accessed on 28 October 2020).

13. Soliman, M.M.A.I. Risk Management in International Construction Joint Ventures in Egypt. Ph.D. Dissertation, University of Leeds, Leeds, UK, 2014.

14. Luo, P.; Sun, Y.; Wang, S.; Wang, S.; Lyu, J.; Zhou, M.; Nakagami, K.; Takara, K.; Nover, D. Historical assessment and future sustainability challenges of Egyptian water resources management. J. Clean. Prod. 2020, 263, 121154. [CrossRef]

15. Khodeir, L.M.; El Ghandour, A. Examining the role of value management in controlling cost overrun [application on residential construction projects in Egypt]. Ain Shams Eng. J. 2019, 10, 471-479. [CrossRef]

16. Ministry of Housing. Urban Facilities and Facilities; Ministry of Housing, Utilities \& Urban Communities: Cairo, Egypt, 1999. 
17. Brundtland, G.H.; Khalid, M.; Agnelli, S.; Al-Athel, S.; Chidzero, B. Our Common Future; Butterworth Heinemann: Oxford, UK, 1987; Volume 8.

18. Kibert, C. Final Session of First International Conference of CIB TG 16 on Sustainable Construction; University of Florida: Gainesville, FL, USA, 1994.

19. Hill, R.C.; Bowen, P.A. Sustainable construction: Principles and a framework for attainment. Constr. Manag. Econ. 1997, 15, 223-239. [CrossRef]

20. Wolstenholme, A.; Austin, S.A.; Bairstow, M.; Blumenthal, A.; Lorimer, J.; McGuckin, S.; Rhys Jones, S.; Ward, D.; Whysall, D.; Le Grand, Z. Never Waste a Good Crisis: A Review of Progress Since Rethinking Construction and Thoughts for Our Future; Constructing Excellence: London, UK, 2009.

21. Abidin, N.Z.; Pasquire, C.L. Revolutionize value management: A mode towards sustainability. Int. J. Proj. Manag. 2007, 25, 275-282. [CrossRef]

22. SAVE. Value Methodology Standard; SAVE Inteernational: Mount Royal, NJ, USA, 2007.

23. Shen, Q. A Knowledge Based Structure for Implementing Value Management in the Design of Office Buildings; University of Salford: Greater Manchester, UK, 1993.

24. Thiry, M. Value Management Practice. Newtown Square, PA: Project; Management Institute: Newtown Square, PA, USA, 1997.

25. Al-Saleh, Y.M.; Taleb, H.M. The integration of sustainability within value management practices: A study of experienced value managers in the GCC countries. Proj. Manag. J. 2010, 41, 50-59. [CrossRef]

26. Parker, D.E. Value Engineering Theory, rev. ed.; The Lawrence D. Miles Value Foundation: Washington, DC, USA, 1998.

27. Alattyih, W.; Haider, H.; Boussabaine, H. Development of Value Creation Drivers for Sustainable Design of Green Buildings in Saudi Arabia. Sustainability 2019, 11, 5867. [CrossRef]

28. Rosłon, J.; Książek-Nowak, M.; Nowak, P. Schedules Optimization with the Use of Value Engineering and NPV Maximization. Sustainability 2020, 12, 7454. [CrossRef]

29. Kim, S.-Y.; Lee, Y.-S.; Nguyen, V.T. Barriers to applying value management in the Vietnamese construction industry. J. Constr. Dev. Ctries. 2016, 21, 55. [CrossRef]

30. Abdelghany, M.; Rachwan, R.; Abotaleb, I.; Albughdadi, A. Value engineering applications to improve value in residential projects. In Proceedings of the Annual Conference-Canadian Society for Civil Engineering, Edmonton, AB, Canada, 27-30 May 2015; pp. 27-30.

31. Aboelmaged, M. The drivers of sustainable manufacturing practices in Egyptian SMEs and their impact on competitive capabilities: A PLS-SEM model. J. Clean. Prod. 2018, 175, 207-221. [CrossRef]

32. Daoud, A.O.; Othman, A.; Robinson, H.; Bayati, A. Towards a green materials procurement: Investigating the Egyptian green pyramid rating system. In Proceedings of the 3rd International Green Heritage Conference, Porto, Italy, 10-12 October 2019.

33. Othman, I.; Kineber, A.; Oke, A.; Khalil, N.; Buniya, M. Drivers of Value Management Implementation in Building Projects in Developing Countries. J. Phys. 2020, 1529, 042083.

34. Aghimien, D.O.; Oke, A.E.; Aigbavboa, C.O. Barriers to the adoption of value management in developing countries. Eng. Constr. Archit. Manag. 2018, 25, 818-834. [CrossRef]

35. Oke, A.; Aghimien, D.; Olatunji, S. Implementation of value management as an economic sustainability tool for building construction in Nigeria. Int. J. Manag. Value Supply Chain. 2015, 6, 55-64.

36. Aarseth, W.; Ahola, T.; Aaltonen, K.; Økland, A.; Andersen, B. Project sustainability strategies: A systematic literature review. Int. J. Proj. Manag. 2017, 35, 1071-1083. [CrossRef]

37. Martens, M.L.; Carvalho, M.M. Key factors of sustainability in project management context: A survey exploring the project managers' perspective. Int. J. Proj. Manag. 2017, 35, 1084-1102. [CrossRef]

38. Fewings, P.; Henjewele, C. Construction Project Management: An Integrated Approach; Routledge: London, UK, 2019.

39. Australia, S. Australian Standard: Value Management (AS 4183-2007); Council of Standards Australia: Sydney, Australia, 2007.

40. Bowen, P.A.; Edwards, P.J.; Cattell, K. Value management practice in South Africa: The built environment professions compared. Constr. Manag. Econ. 2009, 27, 1039-1057. [CrossRef]

41. Ann, T.; Shen, Q.; Kelly, J.; Hunter, K. An empirical study of the variables affecting construction project briefing/architectural programming. Int. J. Proj. Manag. 2007, 25, 198-212.

42. Kelly, J.; Male, S. Value Management in Design and Construction; Routledge: London, UK, 2003. 
43. Abidin, N.Z.; Pasquire, C.L. Delivering sustainability through value management. Eng. Constr. Archit. Manag. 2005, 12, 168-180. [CrossRef]

44. Scotland, B. Report on Value Management Workshops for Community Self Build Scotland, BRE Scotland. Available online: http://goo.gl/rHv5WB (accessed on 10 December 2013).

45. Stephenson, M. How Can Value Engineering Be Used to Enhance the Sustainability of Major Engineering Developments? Master's Thesis, University of Strathclyde, Glasgow, UK, 2003.

46. Hayles, C. The role of value management in the construction of sustainable communities. Value Manag. 2004, $10,15-19$.

47. Al-Yousefi, A.S. The synergy between value engineering and sustainable construction. In Proceedings of the CTBUH 8th World Congress, Dubai, UAE, 3-5 March 2008; pp. 3-5.

48. Kelly, J.; Male, S.; Graham, D. Value Managent of Construction Project; Blackwell: London, UK, 2004.

49. Phillips, M.R. Towards sustainability and consensus through value management: Case study. Managing Sustainable Values. In Proceedings of the International Conference of the Institute of Value Management, Hong Kong, China, 6-7 May 2009.

50. Davis, D.F.; Golicic, S.L.; Boerstler, C.N. Benefits and challenges of conducting multiple methods research in marketing. J. Acad. Mark. Sci. 2011, 39, 467-479. [CrossRef]

51. Buniya, M.K.; Othman, I.; Sunindijo, R.Y.; Kineber, A.F.; Mussi, E.; Ahmad, H. Barriers to safety program implementation in the construction industry. Ain Shams Eng. J. 2020. [CrossRef]

52. Bazeley, P. The evolution of a project involving an integrated analysis of structured qualitative and quantitative data: From N3 to NVivo. Int. J. Soc. Res. Methodol. 2002, 5, 229-243. [CrossRef]

53. Mason, M. Sample size and saturation in PhD studies using qualitative interviews. Forum Qual. Sozialforschung Forum Qual. Soc. Res. 2010, 11, 3.

54. Othman, I.; Kamil, M.; Sunindijo, R.Y.; Alnsour, M.; Kineber, A.F. Critical success factors influencing construction safety program implementation in developing countries. In Proceedings of the 2nd Joint International Conference on Emerging Computing Technology and Sports (JICETS) 2019, Bandung, Indonesia, 25-27 November 2019; p. 042079.

55. Ochieng, E.G.; Price, A.D. Managing cross-cultural communication in multicultural construction project teams: The case of Kenya and UK. Int. J. Proj. Manag. 2010, 28, 449-460. [CrossRef]

56. Haig, B.D. An abductive theory of scientific method. In Method Matters in Psychology; Springer: Berlin/Heidelberg, Germany, 2018; pp. 35-64.

57. Dubois, A.; Gadde, L.-E. Systematic combining: An abductive approach to case research. J. Bus. Res. 2002, 55, 553-560. [CrossRef]

58. Saunders, M.; Lewis, P.; Thornhill, A. Research Methods for Business Students, 6th ed.; Pearson: Harlow, UK; New York, NY, USA, 2012.

59. Fellows, R.F.; Liu, A.M. Research Methods for Construction; John Wiley \& Sons: New York, NY, USA, 2015.

60. Williams, B.; Onsman, A.; Brown, T. Exploratory factor analysis: A five-step guide for novices. Aust. J. Paramed. 2010, 8. [CrossRef]

61. Field, A. Discovering Statistics Using SPSS; Sage Publications: New York, NY, USA, 2009.

62. Thompson, B. Exploratory and Confirmatory Factor Analysis: Understanding Concepts and Applications; American Psychological Associatio: Washington, DC, USA, 2004.

63. Costello, A.B.; Osborne, J. Best practices in exploratory factor analysis: Four recommendations for getting the most from your analysis. Pract. Assess. Res. Eval. 2005, 10, 7.

64. Tabachnick, B.G.; Fidell, L.S.; Ullman, J.B. Using Multivariate Statistics; Pearson: Boston, MA, USA, 2007; Volume 5 .

65. Kim, T.-H.; Lee, H.W.; Hong, S.-W. Value engineering for roadway expansion project over deep thick soft soils. J. Constr. Eng. Manag. 2016, 142, 05015014. [CrossRef]

66. Luvara, V.G.; Mwemezi, B. Obstacles against value management practice in building projects of Dar es Salaam Tanzania. Int. J. Constr. Eng. Manag. 2017, 6, 13-21.

67. Shen, Q.; Liu, G. Critical success factors for value management studies in construction. J. Constr. Eng. Manag. 2003, 129, 485-491. [CrossRef]

68. Kothari, C.R. Research Methodology: Methods and Techniques; New Age International: Delhi, India, 2004. 
69. Adedokun, O.A.; Ibironke, O.T.; Olanipekun, A.O. Vulnerability of motivation schemes in enhancing site workers productivity for construction industry's sustainability in Nigeria. Int. J. Sustain. Constr. Eng. Technol. 2013, 4, 21-30.

70. Sushil, S.; Verma, N. Questionnaire validation made easy. Eur. J. Sci. Res. 2010, 46, 172-178.

71. Chileshe, N.; Rameezdeen, R.; Hosseini, M.R. Drivers for adopting reverse logistics in the construction industry: A qualitative study. Eng. Constr. Archit. Manag. 2016, 32, 134-157. [CrossRef]

72. Kavishe, N.; Chileshe, N. Identifying project management practices and principles for Public-Private partnerships in housing projects: The case of Tanzania. Sustainability 2018, 10, 4609. [CrossRef]

73. King, N.; Horrocks, C.; Brooks, J. Interviews in Qualitative Research; SAGE Publications Limited: Thousand Oaks, CA, USA, 2018.

74. Sharma, G. Pros and cons of different sampling techniques. Int. J. Appl. Res. 2017, 3, 749-752.

75. Ripollés, M.; Blesa, A. International new ventures as "small multinationals": The importance of marketing capabilities. J. World Bus. 2012, 47, 277-287. [CrossRef]

76. Pallant, J. SPSS Survival Guide; Allen \& Unwin: Crows Nest, Australia, 2005.

77. Shen, Q. Value management in Hong Kong's construction industry: Lessons learned. In Proceedings of the SAVE International Conference Proceeding, Hong Kong, China, 16 December 1997; pp. 260-265.

78. Ahadzie, D.; Proverbs, D.; Olomolaiye, P. Critical success criteria for mass house building projects in developing countries. Int. J. Proj. Manag. 2008, 26, 675-687. [CrossRef]

79. Al-Yami, A.M. An Integrated Approach to Value Management and Sustainable Construction during Strategic Briefing in Saudi Construction Projects. Ph.D. Dissertation, Loughborough University, Loughborough, UK, 2008.

80. Lai, N.K. Value Management in Construction Industry. Master's Thesis, Universiti Teknologi Malaysia, Johor Bahru, Malaysia, 2006.

81. SAVE. Value Managemen; SAVE: Dayton, OH, USA, 2008.

82. Jaapar, A.; Maznan, N.A.; Zawawi, M. Implementation of value management in public projects. Procedia Soc. Behav. Sci. 2012, 68, 77-86. [CrossRef]

83. Hwang, B.-G.; Zhao, X.; Toh, L.P. Risk management in small construction projects in Singapore: Status, barriers and impact. Int. J. Proj. Manag. 2014, 32, 116-124. [CrossRef]

84. Mohamad Ramly, Z.; Shen, G.Q. Value management in Malaysia: Past, present and future. In Proceedings of the International Conference on Value Engineering and Management 'Innovation in Value Methodology', Hong Kong, China, 6-7 December 2012; pp. 105-110.

85. Byrne, B. Structural Equation Modeling with AMOS: Basic Concepts, Applications, and Programming, 2nd ed.; Taylor \& Francis Group: New York, NY, USA, 2010.

86. Sharma, S. Applied Multivariate Techniques; John Wiley and Sons: New York, NY, USA, 1996.

87. Pallant, J. SPSS Survival Manual, 3rd ed.; McGrath Hill: Berkshire, UK, 2007; Volume 15.

88. Tavakol, M.; Dennick, R. Making sense of Cronbach's alpha. Int. J. Med. Educ. 2011, 2, 53. [CrossRef]

89. Nunnally, J.C. Psychometric Theory, 3rd ed.; Tata McGraw-Hill Education: New York, NY, USA, 1994.

90. Yu, A.T.W.; Javed, A.A.; Lam, T.I.; Shen, G.Q.; Sun, M. Integrating value management into sustainable construction projects in Hong Kong. Eng. Constr. Archit. Manag. 2018, 25, 1475-1500. [CrossRef]

91. Tanko, B.L.; Abdullah, F.; Ramly, Z.M.; Enegbuma, W.I. An implementation framework of value management in the Nigerian construction industry. Built Environ. Proj. Asset Manag. 2018, 8, 305-319. [CrossRef]

92. Tanko, B.L.; Abdullah, F.; Ramly, Z.M.; Enegbuma, W.I. Confirmatory factor analysis of value management current practice in the Nigerian construction industry. Pernabit Akademia Baru J. Adv. Res. Appl. Sci. Eng. Technol. 2017, 9, 32-41.

93. British Standard EN 12973. Available online: http://bsonline.techindex.co.uk (accessed on 28 October 2020).

94. Zainul-Abidin, N. Achieving sustainability through value management: A passing opportunity? Int. J. Constr. Manag. 2008, 8, 79-91. [CrossRef]

95. Leung, M.; Liu, A.M. Developing a value management model-by value-goal system approach. In Proceedings of the 14th Annual Conference of Association of Researchers in Construction Management (ARCOM 98), Reading, UK, 9-11 September 1998; pp. 496-505.

96. Dallas, M. Revolutionising the Way We Build, Managing Sustainable Values. In Proceedings of the International Conference of the Institute of Value Management, Hong Kong, China, 6-7 May 1999; pp. 6-7.

97. Chougule, A.; Gupta, A.; Patil, S. Application of value engineering technique to A residential Building-Case study. Int. J. Innov. Res. Adv. Eng. IJIRAE 2014, 1. 
98. Chen, W.T.; Liao, S.L. A job-plan based performance evaluation for construction value engineering study. J. Chin. Inst. Eng. 2010, 33, 317-333. [CrossRef]

99. Kelly, J.; Male, S.; Graham, D. Value Management of Construction Projects; John Wiley \& Sons: New York, NY, USA, 2014.

100. Oke, A.E.; Aigbavboa, C.O. Sustainable Value Management for Construction Projects; Springer: Berlin/Heidelberg, Germany, 2017.

101. Kam Shadan, P. Construction Project Management Handbook; Federal Transit Administration: Washington, DC, USA, 2012; Volume 14, p. 2016.

102. Liu, G. A framework for Implementing Value Management in China's Construction Industry. Ph.D. Thesis, The Hong Kong Polytechnic University, Hong Kong, China, 2003.

103. Munyasya, B.M.; Chileshe, N. Towards sustainable infrastructure development: Drivers, barriers, strategies, and coping mechanisms. Sustainability 2018, 10, 4341. [CrossRef]

104. Švajlenka, J.; Kozlovská, M. Perception of user criteria in the context of sustainability of modern methods of construction based on wood. Sustainability 2018, 10, 116. [CrossRef]

105. Švajlenka, J.; Kozlovská, M.; Pošiváková, T. Analysis of selected building constructions used in industrial construction in terms of sustainability benefits. Sustainability 2018, 10, 4394. [CrossRef]

106. Švajlenka, J.; Kozlovská, M. Evaluation of the efficiency and sustainability of timber-based construction. J. Clean. Prod. 2020, 259, 120835. [CrossRef]

107. Spychalska-Wojtkiewicz, M. The Relation between Sustainable Development Trends and Customer Value Management. Sustainability 2020, 12, 5496. [CrossRef]

108. Yates, A.; Yates, A. Sustainable Buildings: Benefits for Designers; Building Research Establishment: London, UK, 2003.

109. Lu, P.; Guo, S.; Qian, L.; He, P.; Xu, X. The effectiveness of contractual and relational governances in construction projects in China. Int. J. Proj. Manag. 2015, 33, 212-222. [CrossRef]

110. Dallas, M.F. Value and Risk Management: A Guide to Best Practice; John Wiley \& Sons: New York, NY, USA, 2008.

111. Kelly, J.; Male, S. A Technique for Understanding the Customer's Project Value Criteria. In Proceedings of Proceedings of the Society of American Value Engineers Conference, Denver, Colorado, 5-8 May 2002.

112. Atabay, S.; Galipogullari, N. Application of value engineering in construction projects. J. Traffic Transp. Eng. 2013, 1, 39-48.

113. Tang, P.; Bittner, R.B. Use of value engineering to develop creative design solutions for marine construction projects. Pract. Period. Struct. Des. Constr. 2014, 19, 129-136. [CrossRef]

114. Lin, G.; Shen, G.Q.; Sun, M.; Kelly, J. Identification of key performance indicators for measuring the performance of value management studies in construction. J. Constr. Eng. Manag. 2011, 137, 698-706. [CrossRef]

115. Kaczmarek, J. The Mechanisms of Creating Value vs. Financial Security of Going Concern—Sustainable Management. Sustainability 2019, 11, 2278. [CrossRef]

116. Zainul-Abidin, N.; Pasquire, C. Moving towards sustainability through value management. In Proceedings of the Joint International Symposium of CIB Working Commissions W55 and W107, Singapore, 22-24 October 2003; Volume 2, pp. 258-268.

117. Lee, W.J.; Mwebaza, R. The Role of the Climate Technology Centre and Network as a Climate Technology and Innovation Matchmaker for Developing Countries. Sustainability 2020, 12, 7956. [CrossRef]

118. Obiora, S.C.; Bamisile, O.; Opoku-Mensah, E.; Kofi Frimpong, A.N. Impact of Banking and Financial Systems on Environmental Sustainability: An Overarching Study of Developing, Emerging, and Developed Economies. Sustainability 2020, 12, 8074. [CrossRef]

119. Figge, F.; Hahn, T. Sustainable value added-measuring corporate contributions to sustainability beyond eco-efficiency. Ecol. Econ. 2004, 48, 173-187. [CrossRef]

120. Jabłoński, A.; Jabłoński, M. Research on business models in their life cycle. Sustainability 2016, 8, 430. [CrossRef]

Publisher's Note: MDPI stays neutral with regard to jurisdictional claims in published maps and institutional affiliations. 